\title{
Motorcycle limb injuries in a developing Country
}

\author{
* K. S. Oluwadiya', L. M. Oginni', A. A. Olasinde \\ and S. O. Fadiora ${ }^{2}$ \\ 'Consultant Orthopaedic Surgeon, ${ }^{2}$ Consultant Surgeon, \\ Department of Surgery, Lautech Teaching Hospital Oshogbo, Osun State \\ ${ }^{*}$ Consultant Orthopaedic Surgeon, Department of Orthopaedic Surgery \\ and Traumatology, Obafemi Awolowo University Teaching Hospitals Complex, Ile-Ife, Osun State \\ ${ }^{4}$ Consultant Orthopaedic Surgeon, Federal Medical Centre, Owo, Ondo State
}

\section{Summary}

Background: Motorcycles have become a very popular means of transportation in Nigeria. This paper is a hospital based study of limb injuries resulting from motorcycle accidents in an urban centre in Nigeria.

Method: All patients reporting to the emergency department of the Obafemi Awolowo University Teaching Hospitals Complex, Ile-Ife with limb injuries resulting from motorcycle accidents between June 1998 and May 1999 were selected for this prospective study.

Result: One hundred and fifteen (79.3\%) out of the 145 victims of motorcycle accidents that reported to the hospital had injuries involving their limbs. The Male: Female ratio was 2.8:1. The mean age was $31.9 \pm 16.7$ (S. D.) years, and 20 - 29years; the most commonly involved age group. $42.2 \%$ were due to collision with automobiles, $22 \%$ pedestrian while $8.7 \%$ were collisions between motorcycles. The use of protective/safety devices was practically non-existent. Seventysix (66.1\%) patients had lower limbs injuries, $25(21.7 \%)$ patients had upper limb injuries while the remaining 14 (12.2\%) injured both upper and lower limbs. The tibia was the most commonly fractured bone (32 patients, $27.8 \%$ ) followed by the femur (25 patients, $21.7 \%$ ). Eighty-six patients $(\mathbf{7 4 . 8 \%})$ with fractures were managed by close reduction and splinting. Eighteen (15.7\%) patients had inter. nal fixation.

Conclusion: Motorcycle accident is an important cause of limb injuries in the developing worlds. Motorcyclists need to be encouraged to use protective/safety devices.

Keywords: Motorcycle, Limb injury, Accident treatment.

\section{Résumé}

Introduction: Les motocycletes sont devenues des moyens de transports très à la mode au Nigéria. Cet article est basé sur une étude hôspitalier des blessures de membre suite aux accidents de moto dans un centre urbain au Nigéria.

Méthode: Tous les patients qui se sont présenté au départment d"urgence du centre complexe hospitalo universitaire d'Obafemi Awolowo, Ile-Ife avec des blessures du membre suite aux accidents de moto entre juin 1998 et mai 1999 ont été choisi pour cet étude en perspective.

Résultat: Cent quinze soit 79,3\% sur 145 accidents de moto qui se sont présentés a 1:hôpital avaient des blessures impliquant leurs membres. La proportion Homme:Femme etait 2,8:1. L'âge moyen etait 31,9+16.7 (S. D.) ans, et $20-29$ ans. Group d'âge le plus concerne. $42,2 \%$ ont ete cause par une collision avec des automobiles, $22 \%$ piétons, tandis que $8,7 \%$ étaient des collisions entres des motocyclettes. L'utilisation du protecteur de sécurite était un pratique inexistent. Soixante seize soit $66,1 \%$ des patients avaient des blessures dans les membres inférieurs, 25 soit $21,7 \%$ des patients avaient des blessures dans les membres supérieurs tandis que les autres 14 soit $12,2 \%$ avaient des blessures dans les membres supérieurs et inférieurs les deux. Le tibia etait l'os le plus fracturé ( 32 patients, soit $27,8 \%$ ), suivi par le femur ( 25 patients, $21,7 \%)$. Quatre vingt six patients soit $(74,8 \%)$ avec des fractures ont été soigne à travers la réduction ferme et éclissement d'un membre. Dix huit soit $15,7 \%$ des patients avaient eu une fixation interne.

Conclusion: Accident de moto est une cause très importante des blessures du membre dans les pays en voie de dévéloppement. Les motocyclistes ont bessoin d'être encouragé de utiliser le'dispositifs de sécurité.

\section{Introduction}

There is a general agreement that road traffic accidents have taken on the characteristics of a mass disease of epidemic proportions ${ }^{1,2}$

Motorcycle accidents are the second most common cause of road traffic accidents in both developed and developing countries $^{3-5}$. The proportion of road traffic accident victims made up of motorcycle falls within $9 \%$ and $35 \%{ }^{3.9}$. Both the case fatality and the injury rate are higher in motorcycle accident than automobiles ${ }^{1,10,11}$. There is a 17 time greater chance of fatality in motorcycle accident trauma than in those involving automobiles. The motorcyclist is also more likely to be injured in $80-90 \%$ of the times when involved in accidents ${ }^{11}$.

There is a wide variation in the Male: Female ratio reported in literature but all showed a greater male involvement 3, 12, 13. The peak ages of incidence in most studies fall in the late teens to the late twenties ${ }^{6,13}$. Factors which have been found to have an effect on the incidence of motorcycle accidents are the season, the day of the week as well as the time of the day ${ }^{14}$. The severity of the injury sustained in such accidents is influenced by the mode of involvement and the use of protective devices ${ }^{7,14.15}$.

There has been an increase in the use of motorcycles in Nigeria largely on account of its rising popularity as a form of commercial transport. Motorcycles are able to ply roads that are too narrow or too rough for automobiles and they are also able to manoeuvre in traffic pile-ups. While mortality in motorcycle accident is largely due to head injury ${ }^{16}$, limb injury is the leading cause of morbidity ${ }^{14}$.

This prospective study was carried out in the Obafemi Awolowo University Teaching Hospital Complex, Ile - Ife, Nigeria to study motorcycle limb injuries.

\section{Patients and Methods}

This prospective study was carried out in the Ife State Hospital. Ile - Ife, and the Wesley Guild Hospital, Ilesa, units of the Obafemi Awolowo University Teaching Complex, Ile - 
Ife, Osun State of Nigeria. Both towns are about 30 kilometres apart and are located along a major road network linking various urban and semi-urban centres in the south western part of Nigeria. The people are mainly farmers, self-employed artisans and traders.

All patients that came to the accident and emergency unit of the hospitals between June 1st 1998 and May 31st 1999 who were victims of motorcycle accident were fully assessed according to a designed pro-forma that had been checked in a pilot study. The information gathered included age, sex and the occupation of the patients, the date and time of the injury, type of accident, mode of involvement, and the use of safety devices. The patients were examined to assess the nature of their injuries and their other vital functions evaluated. Investigations were carried out as necessary.

The patients were followed up for at least one year. The eventual outcome of treatment of all the patients in the study were reviewed and recorded as any one of six possible outcomes; (1) satisfactory; (2) unsatisfactory; (3) discharged against medical advice; (4) lost of follow up; (5) referred and (6) dead. A satisfactory outcome is one in which the patient is fully recovered by a year of follow up but if the patient still has complications either as a result of the initial injury or the subsequent treatment the outcome is deemed unsatisfactory. A patient is said to have been lost-to-follow-up if he/she defaults from the clinic before one year. Clinical, operative and post mortem findings will be used in ascertaining the final and correct diagnosis. The data was analysed with Statistical Package for the Social Sciences (SPSS) software. The means, standard deviation and ranges were determined and the chi-square test was used for test of association. The significant level was put at $\mathrm{P}<0.05$.

\section{Result}

One hundred and forty-five victims of motorcycle accident were seen in the accident and emergency department representing $1.3 \%$ of all accident and emergency attendants and $21.3 \%$ of all road traffic accident victims. One hundred and fifteen $(79.3 \%)$ of these patients had injuries involving the limbs.

The ages of the patients ranged from 2 to 79 years with a mean of $31.9 \pm 16.7(\mathrm{SD})$ years. More than two-thirds of the patients were less than 40 years old, the age group 20 - 29 most commonly injured. There were $85(74 \%)$ males and 30 (26\%) females, representing a male: female ratio of 2.8:1. Table 1 shows the relationship between the patient's sex and the mode of involvement. No female was involved as a rider. Figure 1 on the other hand reveals the relationship between the patient's mode of involvement and the age group. There were no riders in the extreme age groups (0-9 and 70-79 years) whereas most of the pedestrian injuries occurred in the same

Table 1 Frequency distribution of the patients' mode of involvement and sex

\begin{tabular}{lccc}
\hline Mode of involvement & Male & Female & Total \\
Riders & 48 & 0 & 48 \\
Passengers & 24 & 17 & 41 \\
Pedestrians & 13 & 13 & 26 \\
Total & 85 & 30 & 115 \\
\hline
\end{tabular}

decades.

Table 2 Distribution of the patients according to the type of collision in which they were involved.

\begin{tabular}{lcc}
\hline Type of accidents & $\begin{array}{c}\text { Numbers of } \\
\text { Patients }\end{array}$ & Percentage \\
Collision with motor vehicles & 52 & 45.3 \\
Pedestrian accidents & 26 & 22.6 \\
Collision with another motorcycle & 10 & 8.7 \\
Enter pothole and lost control & 9 & 7.8 \\
Run off the road & 6 & 5.2 \\
Heel caught in the spokes of & & \\
the back wheel & 4 & 3.5 \\
Collision with animal & 2 & 1.7 \\
Collision with roadside object & 1 & 0.8 \\
Others & 5 & 4.4 \\
Total & 115 & 100.0 \\
\hline
\end{tabular}

Table 3 Distribution of injuries to the various types of tissues in the limbs

\begin{tabular}{lcc}
\hline Type of tissue injured & $\begin{array}{c}\text { Number of } \\
\text { patients }\end{array}$ & Percentage \\
Skin & 88 & 33.0 \\
Bones & 79 & 29.7 \\
Joints & 32 & 11.9 \\
Muscles & 17 & 6.3 \\
Tendons & 5 & 1.9 \\
Nerves & 2 & 0.7 \\
Other parts of the body & 41 & 16.5 \\
Total & 264 & 100.00 \\
\hline
\end{tabular}

Many patients had multiple injuries: average $=2.3 /$ patient.

Table 4 Patient's surgical procedures

\begin{tabular}{lcc}
\hline Choice of Procedure & Patients & Percentage \\
Debridement & 30 & $29.4 \%$ \\
Primary closure & 30 & $29.4 \%$ \\
ORIF & 18 & $17.6 \%$ \\
Secondary closure & 8 & $6.9 \%$ \\
Tendon repair & 5 & $4.9 \%$ \\
Skin grafting & 3 & $2.9 \%$ \\
Patellectomy & 2 & $2.0 \%$ \\
Above knee amputation & 1 & $1.0 \%$ \\
Other surgeries & 7 & $5.9 \%$ \\
Total & 104 & $100.0 \%$ \\
\hline
\end{tabular}

$2(3.2 \%)$ patients had 4 surgical procedures, $3(4,9 \%)$ had 3.20 (32.8\%) had 2 while the remaining $38(62.3 \%)$ had one.

\section{Hourly, daily and monthly incidence}

Most of the accidents occurred between 2p.m. (1400hrs) and 4p.m. (1600hrs) local time, a slightly lower incidence also occured between 6p.m. (1800hrs) and 8 p.m. (2000hrs) local time. Fifty-two point two percents $(52.2 \%)$ of the accidents occurred on Thursdays, Fridays and Saturdays. Fridays and Saturdays are weekends when social activities are at their highest. Sixty-three percent of the accidents also occurred between June and October, the raining season when motorcycle riding can be hazardous. June, the month with the highest rainfall had the highest monthly incidence.

\section{Site of accident}

Accidents on roads within urban areas accounted for 
Table 5 Complications after treatment

\begin{tabular}{|c|c|c|c|}
\hline \multirow[t]{2}{*}{ Complications } & \multirow[t]{2}{*}{ Number of patients } & \multicolumn{2}{|c|}{ Percentage } \\
\hline & & $\begin{array}{c}\% \text { of } \\
\text { patients }\end{array}$ & $\begin{array}{c}\% \text { of } \\
\text { injuries }\end{array}$ \\
\hline Joint stiffness & 60 & 63.8 & 23.4 \\
\hline Muscle weakness & 47 & 50.0 & 18.1 \\
\hline Limb oedema & 31 & 33.0 & 12.0 \\
\hline Muscle atrophy & 25 & 26.6 & 9.7 \\
\hline Wound infection & 15 & 16.0 & 5.8 \\
\hline Delayed union & 14 & 15.0 & 5.7 \\
\hline Osteomyelitis & 13 & 13.8 & 5.2 \\
\hline Shortening & 11 & 11.7 & 4.3 \\
\hline Malunion & 8 & 8.5 & 3.1 \\
\hline Nerve palsy & 5 & 5.3 & 2.1 \\
\hline Hypertrophic scar & 5 & 5.3 & 2.1 \\
\hline Non union & 4 & 4.3 & 1.5 \\
\hline Joint deformity & 4 & 4.3 & 1.5 \\
\hline Tendon lesion & 4 & 4.3 & 1.5 \\
\hline Plaster sore & 3 & 3.2 & 1.2 \\
\hline Reaction to skin traction & 2 & 2.1 & 0.8 \\
\hline Wound breakdown & 2 & 2.1 & 0.8 \\
\hline Pin tract infection & 2 & 2.1 & 0.8 \\
\hline Re-fracture & 1 & 1.1 & 0.4 \\
\hline Total & 256 & & 100.00 \\
\hline
\end{tabular}

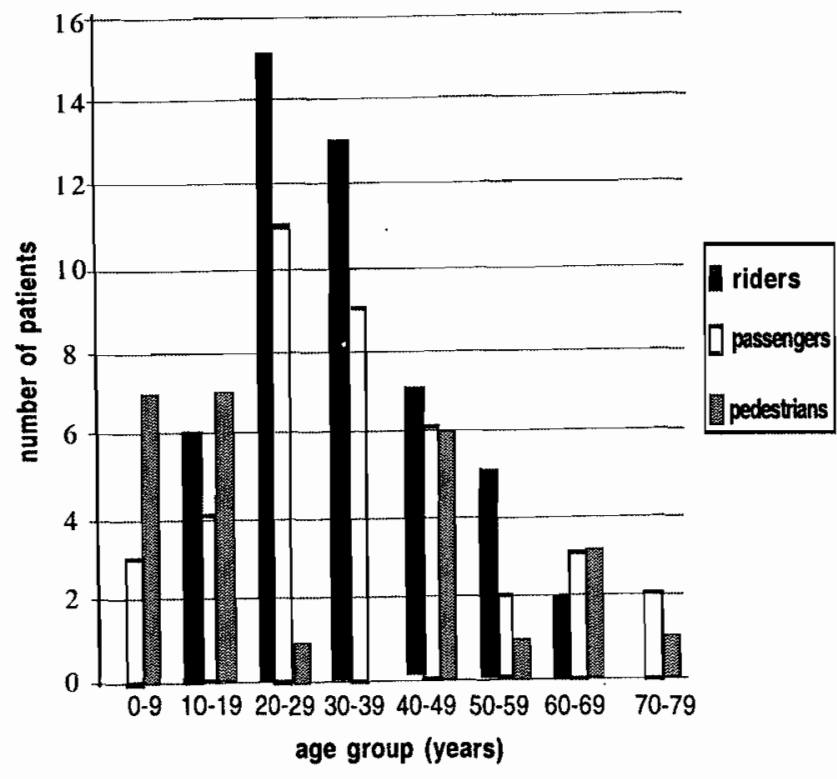

Fig. 1 Age group and mode of involvement of the patients

$79.1 \%$ of the victims while the remaining $20.9 \%$ occurred on intercity roads. There was a significant association between the accident site and the severity of injury being worse on intercity roads $(P=0.041)$. Likewise, in motorcycle with two passengers, the intercity accident is also more likely to injure both passengers $(P=0.0032)$.

\section{Mode of involvement}

Forty-eight $(41.7 \%)$ were riders, $41(35.7 \%)$ passengers and the remaining $(22.6 \%)$ pedestrians. Eighty-three and a half percent $(83.5 \%)$ of these accidents involved motorcycles while the remainders involved scooters. There was no significant association between the mode of involvement and the limb injured or the outcome of treatment.

\section{Number of passengers on the motorcycle}

Eighty-nine (77.4\%) patients were injured as commuters on the motorcycles, in $26(29.2 \%)$ accidents, the motorcycle was carrying only the rider, $55(61.8 \%)$ cases involved the rider and a passenger on the motorcycle while in $8(9.0 \%)$ cases, the rider had two passengers. The passenger rather than the rider is more likely to be injured when the motorcycle is carrying two or more persons $(\mathrm{p}=0.01)$. More than $90 \%$ of the accidents that occurred as a result of the rider losing control had more than one person riding on the motorcycle at the time.

\section{Type of collision}

Table 2 shows how the patients sustained their fractures. Fifty-two (45.3\%) accidents were collisions with motor vehicles which on further analysis showed that collisions with moving vehicles was the most common $(44,84.6 \%), 6$ $(11.5 \%)$ riders collided with vehicle doors that were suddenly opened and $2(3.9 \%)$ with stationary vehicles. There was a significant association between the type of collision and the severity of the injury sustained $(P=0.015)$ : a coltision with moving vehicles is more likely to result in severe injuries. Likewise, in cases involving motorcycles with multiple passengers, there was an association between the type of accident and the likelihood of injuries to everyone on the bike $(P$ $=0.00029$ ): collisions between two motorcycles showed the greatest propensity towards simultaneous injuries to both passengers on the machine. Thirty-nine (75\%) of the $52 \mathrm{pa}$ tients injured in motorcycle collisions with motor vehicles sustained injuries to the lower limbs compared to patients who sustained their injuries in inter-motorcycle collisions with $30 \%$ lower limbs involvement.

\section{Type of garment}

In Nigeria, the traditional dresses are flowing and are likely to billow out at speed. Eighty-nine (77.4\%) patients were involved as either passengers or riders; of these, 35 $(39.3 \%)$ patients were wearing traditional dresses at the time of accident while the remaining $54(60.7 \%)$ patients were wearing shirts, trousers or vests which are less likely to billow out. None wore special protective clothing at the time of accident. A greater percentage of the passengers $(53.7 \%)$ were wearing traditional dresses compared to riders $(27.1 \%)$. Again, $89.2 \%$ of the patients wearing loose garments at the time of accident sustained severe injuries compared with $70.9 \%$ in the other group.

\section{The use of alcohol}

Every patient was asked if the motorcycle rider who cause his/her accident was drunk, only 101 (87.8\%) of them responded with certainty, $16(15.9 \%)$ of these reported the rider drunk. Nine $(56 \%)$ of the positive respondents were riders, 5 $(31.3 \%)$ pedestrians and $2(12.6 \%)$ passengers. When one compares this proportion with that for all the 115 patients (rider $=41.7 \%$; passenger $=35.7 \%$; pedestrian $=22.6 \%$ ), it reveals the greater vulnerability of pedestrians to drunken motorcyclists: On the other hand, passengers appeared to be more immune; in fact, the two passengers affected were also drunk at the time of accident. This seeming immunity 
may be because a sober passenger may be very unwilling to ride along with a drunken rider.

Drink related injuries were also more common in the evening: 10 of the 16 accidents occurred between $6 \mathrm{p} . \mathrm{m}$. and 8 p.m. Thirty-five percent of such accidents occurred on Saturdays.

\section{Occupation}

Twenty-seven percent were students, $13.1 \%$ were artisans while $11.3 \%$ each were commercial motorcyclists and junior civil servants. Most of these people belonged to the lower classes economically and socially. Even though only 13 of these patients were commercial motorcyclists, 21 passengers were paying customers on commercial motorcycles.

\section{Injuries}

Twenty-five (21.7\%) patients injured the upper limbs, $76(66.1 \%)$ the lower limbs and the remaining $14(12.2 \%)$ had injuries to both upper and lower limbs.

Overall the patients sustained 264 injuries. Table 3 showed the distribution of the various injuries. Forty-one (35.6\%) patients also had injuries involving other parts of the body and among these the head was the most commonly injured with 32 cases i.e. $78 \%$ of injuries in other regions of the body. There were $79 \mathrm{limb}$ fractures with the tibia involved in 32 cases (with fibula in 25), and the femur accounted for 25. The humerus is the most commonly fractured bone in the upper limb. Twenty-seven (33.4\%) patients sustained open fractures. The tibia accounted for $18(66.7 \%)$ of these. The knee accounted for $13(38.2 \%)$ of the 34 patients with joint injuries.

\section{Treatment}

Sixty-one (53.0\%) patients had surgery (Table 4). Eightysix patients with fractures and joint injuries were managed with close reduction and splinting with Plaster of Paris POP, tractions, strapping or slings.

The mean duration of immobilization was $53.5 \pm 41.6(\mathrm{SD})$ days and the range, 7-257 days. The mean duration of hospitalization was $30 \pm 27$ (SD) days and a range was 1-154 days. Nineteen $(16.5 \%)$ patients had blood transfusion and 79 $(68.7 \%)$ patients were given antibiotics either perioperatively or for open wounds or fractures.

\section{Complications}

Two hundred and fifty-six complications were observed which gives a complication rate of 2.23 per patient.

\section{Outcome}

After one year of follow-up, $59(51.3 \%)$ patients had satisfactory outcomes and $26(22.6 \%)$ patients had unsatisfactory outcomes. Fourteen (12.2\%) patients discharged themselves against medical advice, $9(7.8 \%)$ were lost to follow-up and $3(2.6 \%)$ were referred to other hospitals for further treatments. Four patients died giving a mortality rate of $3.5 \%$.

\section{Discussion}

Due to the advent of technology, the pattern of injuries in Africa is changing ${ }^{17}$. One of the causes of this changing pattern is road traffic accident ${ }^{18}$ of which motorcycle accident is an important part ${ }^{2,15}$.

In this study, motorcycle accidents accounted for $21.5 \%$ of all road traffic accident trauma cases. This falls within the 9-35\% range reported in the literature ${ }^{4.9}$.

The peak age of 20-29 years in this study agrees with the 18-30 years and 25-29 years peak period reported from other parts of Nigeria ${ }^{6,8}$. It is however higher than the 16-25 years and the $10-19$ years reported from industrialized countries ${ }^{(12}$ 19). The reason for the older age group of peak occurrence may be due to a delayed access to motorcycles. The age group 20-29 years is an age group under significant social and economic pressure. Thus, they are often prepared to take any available means of transportation to their destination. There is a preponderance of males over females in most reported series ${ }^{3,10}$. The ratio in this study is $2.8: 1$. But women and children form a disproportionately large percentage of pedestrian victims ${ }^{4,8,14}$. Fifty percent of the pedestrians in this study were females and $45.9 \%$ were children below fourteen years. It is worthy of note that the only age group in which females outranked males is the 0-9 year age group. Female children mature earlier than their male counterparts, and hence are wont to be active earlier. In addition, young girls are more likely to be hawking food on the streets while boys are playing football.

The passengers in this study stood a higher risk of sustaining injury than riders as shown by the fact that a lower percentage of passengers reported a simultaneous injury to their co-rider. This agrees with the study done by Bothwell in England ${ }^{14}$. The behaviour of many motorcyclists on the road makes them particularly vulnerable to injuries ${ }^{20}$. For example, 7 of the 10 inter-motorcycle collisions occurred at dusk when there was poor visibility and one or both of the motorcycles were without headlights. Many patients especially the passengers were wearing traditional garments when the accidents occurred; these garments are loose and have a tendency to flap and billow out even at moderate speeds. This may disrupt the rider's vision or be caught in the bike's moving parts with consequent loss of control. In 8 cases, 3 persons were on the motorcycle when the accident occurred, a fact that may have contributed to their crash.

In South Western Nigeria, the rainy season extends from April to September ${ }^{6}$. More accidents occurred in the rainy season than in the dry season. This agrees with an earlier study done in the same region ${ }^{6}$. The combination of a wet driving surface, reduced visibility and exposure to the elements make motorcycle riding when it is raining very hazardous. There are some other road situations that are almost unique to developing countries, which make motorcycle riding hazardous. Thus 9 patients were injured when the motorcycles on which they were riding crashed into potholes and 2 others collided with stray animals.

Most published results of daily occurrence of road traffic accidents reported Saturdays and Sundays as days with the highest incidence ${ }^{3,6,12}$. However, a few authors reported Sunday with a much lower incidence ${ }^{1}$. This study agrees with the last one. The reason may be because many of the bikes involved are used for commercial activities. Therefore on Sundays, the traditional day of rest, the bikes were not 
ridden. More accidents occurred in the afternoon/evening period than at any other time is in agreement with most published works ${ }^{6,12,22}$. These are the hours of the highest traffic volume when workers will be returning from work and students from schools.

The use of protective/safety devices was practically nonexistent. None of the victims was wearing hemet at the time of injury. Only a few motorcycle had leg-guards, none had fairing or windscreen and no patient wore protective clothing.

Most studies showed a preponderance of limb injuries ${ }^{6}$ $7,10,12$ but the proportion differed. It ranged from $40.3 \%{ }^{12}$ to $64 \%{ }^{7}$. The $79.20 \%$ found in this study is higher than reported in literature probably because both skeletal and soft tissue injuries to the limb were included. When only fracture (i.e. 79) were used and it was based on all motorcycle accidents victims that were seen in the casualty (i.e. 145), and not only on those with limb injuries, then the proportion fell to $54.5 \%$ which falls within the range as reported in literature.

After skin injuries, fractures were the most common injuries seen; the majority of these were closed $(65.8 \%)$. This is close to the $66.9 \%$ (107 of 160 ) reported by Zettas ${ }^{13}$, but lower than the $86 \%$ (207 of 240 ) reported by Deaner ${ }^{10}$. However Deaner's series was done on military personnel who by regulation may have been wearing protective clothing with consequently reduced tendency to injure the skin.

That the prognosis of motorcycle injuries is worse in developing countries is well documented ${ }^{2,6,23}$. Factors such as poor pre-hospital and hospital care and late presentation in hospitals are responsible for this ${ }^{24}$.

The mortality rate reported in this study is comparable to that seen elsewhere in Africa ${ }^{6}$ and also from the developed countries ${ }^{10,12}$. But this does not mean that the severity of injuries is the same ${ }^{24}$. Most of the patients who required urgent treatment may have died either at the scene of accident or in transit to the hospital because of poor pre-hospital care ${ }^{24}$.

The facilities needed to improve survival of these patients are expensive and beyond the economic capabilities of most third world countries. However accident prevention and effective pre-hospital care are recognised ways of attaining this goal ${ }^{25,26}$. The fact that the later strategy is vastly cheaper than the former should make it more attractive to developing countries $^{24}$.

Finally, there is a need to increase the awareness of roadusers to safety oriented road behaviour. The motorcyclist should also be encouraged or enforced to use protective devices.

\section{References}

1. Simpson J: An epidemiological approach to road accidents. The practitioner. $1662 ; 188: 515-528$.

2. Oyemade GAA, Oluwole $S$ : The pattern of fractures in an African community. Nigerian Medical Journal 1978; 8: 21 24.

3. Adeloye A and Odeku EL: The pattern of Road traffic accidents seen at the University College Hospital, Ibadan, Nigeria: A preliminary study. West African Medical Journal. 1970: $153-157$
4. Oyemade A: Epidemiology of road traffic accidents in Ibadan and it's environs. Nigerian Medical Journal 1973; 3: 174 - 177.

5. Aniekan UE: Motorcycle accidents and lower limb bony injuries. The Calabar experience. Faculty of surgery dissertion, National Postgraduate Medical College of Nigeria, 1989.

6. Odelowo EOO: Pattern of trauma resulting from motorcycle accidents in Nigerians: A two year prospective study. African Journal Medicine and Medical Sciences 1994; 23: 109 112.

7. Ross DJ: The prevention of leg injuries in motorcycle accidents. Injury (Year)? 15: $75-77$.

8. Asogwa SE: The child in the road transport system in Nigeria. Nigerian Medical Journal 1984; 14: 37 - 42.

9. Odelowo EO: Factors affecting morbidity and mortality from road traffic accidents: a Nigerian peri-urban study. African Journal Medicine and Medical Science 1993; 22: 69 - 74.

10. Deaner RM and Fitchett VH: Motorcycle trauma. J. Traurna $1975 ; 15,678-681$

11. Committee on Medical aspects of automotive safety: Medical aspects of motorcycle safety. Journal of American Medical Association. 1968; 205: 92 - 93.

12. Haddah JP, Echave V and Brown RA et al. Motorcycle accidents: A review of 77 patients treated in a three month period. Journal of Trauma 1976; 16: 550 - 557.

13. Zettas JP, Zettas $P$ and Thanasophon B: Injury pattern in motorcycle accidents. Journal of Trauma 1976; 19: 833 - 836

14. Bothwell PW: The problem of motorcycle accidents. The practitioner 1962; 188: 474 - 487.

15. Mcfarland RA: The role of human factors in accidental trauma. The American Journal of the Medical Sciences 1957; (Vol?) 1 26.

16. Umebese PFA and Okukpo SU: Motorcycle accidents in a Nigerian university campus. A one year study of the pattern of trauma sustained in university of Benin campus. Nigerian Journal of Clinical Practice. 2001; 4: 33 - 36.

17. Jaja MOA: The changing pattern of injuries in Africa. West African Journal of Surgery. 1976; 1: 162-166.

18. Ransome-Kuti $\mathrm{O}$ : The problems of peadiatric emergencies in Nigeria. Nigerian Medical Journal 1972; 2: 62

19. Kumar JM: Motorcyclist - menace to whom? Brit. J. A. \& Med. $1989 ; 1: 40-41$.

20. Owoshina FAO: The traffic scene in Nigeria - An African example. The WHO/OBCD/World Bank's Conference on road traffic accidents in developing countries. Mexico city $9-13$ November, 1981.

21. Kraus JF, Riggins RS and Franti CE: Some epidemiological features of motorcycle collision injuries II \& I. American 
Journal of Epidemiology. 1975; 102: 74-113.

22. Korsa $\mathrm{KG}$ in Ancillary support for the care of the injured. In Adeloye A. (ed) Care of the injured. Ibadan: West African College of Surgeons. 1977; $199-202$.

23. Oyediran ABOO in Trauma: An epidemic. In Adeloye A. (ed.) Care of the injured Ibadan: West African College of Surgeons 1977; $15 \cdot 21$.
24. Adesunkanmi ARK, Oginni LM and Oyelami et al.: Epidemiology of childhood injury. The journal of trauma: injury, infection and critical care. 1998; 44: $506-511$.

25. Trunkey DD: Overview of trauma, Surgical Clinics of North American 1982; 62, 3 - 7 .

26. West JG, Trunkey DD and Lim RC: Systems of trauma care, a study of two countries. Archives of Surgery 1979; $114: 455$ 460. 